\title{
MITIGATION A HARMFUL EFFECTS OF LIVESTOCK ON THE ENVIRONMENT IN UKRAINE
}

\author{
Oleksandr Labenko ${ }^{1}$
}

\section{Summary}

The potential to reduce the sectors (livestock) emissions is large. Technologies practices that help reduce emissions exist but are not widely used. The adoption and use of best practices and technologies by the bulk of the world's producers can result in significant reductions in emissions.

The FAO report indicated that the emissions could be reduced by between 18 and 30 percent (or 1,8 to 1,1 gigatones $\mathrm{CO}_{2}-e q$ ), if producers in a given system, region and climate adopted the practices currently applied by the 10 to 25 percent of producers with the lowest emission intensity.

Most of the technologies and practices that mitigate emissions also improve productivity and can contribute to food security and poverty alleviation as the planet needs to feed a growing population.

Under the conditions of the limited financial resources for the purpose of the implementation of government programs to minimize the harmful farm animal waste, such funds can be raised by participating in the emissions market.

Key words: manure management, funds, trade schemes.

JEL: Q160, Q280, H230

\section{Introduction}

According to the forecast, population will grow up to 8, 92 billion by 2050 (DESA) as a result, food crises will be strengthened. The agriculture development may solve the food crises issue, especially - livestock. But if we increase the size of livestock production the volume of $\mathrm{CO}_{2}$ pollution will also increase in the world. In this research we analyse, how an animal husbandry will be developed in Ukraine and the ways of mitigation the volumes of harmful emissions of $\mathrm{CO}_{2}$.

Greenhouse gas emissions by the livestock sector could be cut by as much as 30 percent through the wider use of existing best practices and technologies, according to a new study

1 Oleksandr Labenko, Ph.D., docent, National University of Life and Environmental Science of Ukraine, Kyiv, 11 Geroyiv oborony Street, Phone: +380 672967 336, E-mail: labenko@ukr.net 
released today by the UN Food and Agriculture Organization (FAO), (Gerber et al., 2013).

The three major GHGs (greenhouse gases) emitted from food and agriculture chains are covered - namely methane $\left(\mathrm{CH}_{4}\right)$, nitrous oxide $\left(\mathrm{N}_{2} \mathrm{O}\right)$ and carbon dioxide $\left(\mathrm{CO}_{2}\right)$.

Greenhouse gas (GHG) emissions associated with livestock supply chains add up to 7.1 gigatonnes (GT) of carbon dioxide equivalent $\left(\mathrm{CO}_{2}\right.$-eq) per year, or 14.5 percent of all human-caused GHG releases (Gerber et al., 2013).

The main sources of emissions are: feed production and processing (45 percent of the total), outputs of GHG during digestion by cows (39 percent), and manure decomposition (10 percent). The remainder is attributable to the processing and transportation of animal products (Gerber et al., 2013).

According to the World Bank date, number of animals per 1ha of agricultural lands in Ukraine was close to 45 thousand units in 2011. At the same time, this index in the countries of the European Union is lower - 20 thousand units, the world's index shows about 16 thousands units (World Bank). On the one hand, increasing the number of animals positively influences on food supply, but the others, there is a negative factor of influence a stockbreeding on environment - greenhouse gases emissions.

GHG emissions from manure management consist of methane and nitrous oxide gases from aerobic and anaerobic decomposition processes. The FAOSTAT emission data are computed at Tier 1 following (IPCC, 2006).

The term manure includes both urine and dung (i.e., both liquid and solid material) produced by livestock. More specifically, $\mathrm{CH}_{4}$ gas is produced by anaerobic decomposition of manure stored or treated, while $\mathrm{N}_{2} \mathrm{O}$ is produced directly by nitrification and de-nitrification processes in the manure, and indirectly by nitrogen $(\mathrm{N})$ volatilization and re-deposition processes, as well as from leaching of manure $\mathrm{N}$.

The wider use of anaerobic digestion results in lower $\mathrm{CH}_{4}$ emissions and generates biogas that can substitute other form of energy (Gerber et al., 2013).

The mitigation potential ranges from 11 to 14 percent in Western Europe and from 11 to 17 percent in Australia and New Zealand. It is higher in North America (25 to 28 percent) due to the greater potential of replacing manure lagoons with anaerobic digesters (Gerber et al., 2013).

By estimates (Gerber et al., 2013), potential in $\mathrm{CO}_{2}$ reduction is $2,4 \%$ due to its decreasing of emission in the OECD Members States in Western Europe.

\section{Research Results}

During the last decade we could observe livestock recession on all animal species in Ukraine. But looking at that the fact that Ukrainian cattle livestock were in five times more in 1991, so the potential to accumulation of their quantity rather considerable. At the end of 2012 in Ukraine the output of all types of producing of meat make about 3000 thousand tons and about 12000 thousand tons of milk (Figure 1). 
Stockbreeding is a source of formation of renewable source of energy and makes the biomass in the form of manure which in turn is an organic fertilizer. At the same time, it is inefficient to use everyday manure during 3 years. After its processing by biogas installation, it can be used at once, because the remaindering mass are prepared, environmentally pure, firm bio fertilizers (humus), without nitrates, seeds of weeds, pathogenic micro flora, eggs of helminths and the other harmful elements. In turn, manure processing by biogas can give the people threefold benefits:

1) New source of power

2) Reduction of greenhouse gases emissions

3) Fertilizers.

Figure 1. The output of major livestock products in Ukraine

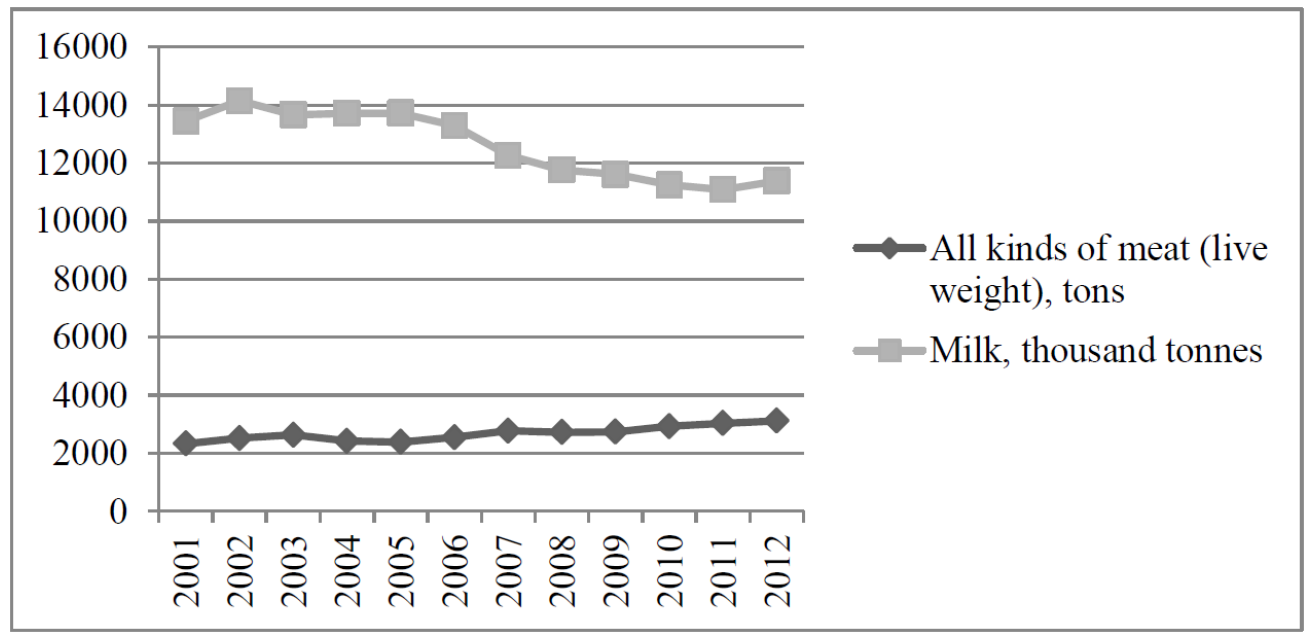

Source: www.ukrstat.gov.ua

Mitigation policy approaches available to policy makers are not unique to climate change or to livestock. They are broadly the same for most environmental management and development issues (Gerber et al., 2013).

Extension and agricultural support services: this suite of approaches facilitates practice change for mitigation and development by providing access to improved practices/ technologies, knowledge and capacity for their application and information about emerging market opportunities. Commonly used approaches include communication, training, demonstration farms and networks to facilitate linkages among sector stake-holders.

Research and development: research and development is necessary to build the evidence base for mitigation technologies/practices. It can play an important role in refining existing technologies/practices to increase their applicability and affordability, and is also necessary for increasing the supply of new and improved mitigation technologies/practices. 
Financial incentives: includes either 'beneficiary pays' mechanisms (abatement subsidies) or 'polluter pays' mechanisms (emissions tax, tradable permits). These are economically efficient mechanisms for incentivizing the adoption of mitigation technologies/practices.

Regulations: includes assignment of mitigation targets for farmers/sectors, as well as more prescriptive approaches such as mandating the use of specific mitigation technologies and practices.

Market friction instruments: includes instruments that seek to increase the flow of information about the emissions associated with different livestock commodities (e.g. labelling schemes). This can help consumers and producers to better align their consumption and production preferences with the emission profiles of these commodities.

Advocacy: includes the raising of awareness about livestock's role in tackling climate change to influence and promote mitigation policy development for the sector (e.g. through intergovernmental representation of this issue in the UNFCCC (United Nations Framework Convention on Climate Change) negotiation process).

In this research the main attention is paid to the government support of biogas production. The biogas installations, creating in Europe, can be divided into three categories. To the biogas installations of the first category concerned: receiving a biogas from manure, use of the dumped amount as organic fertilizers, ensuring the requirements of household in heating and electricity. Installations of this type differ by simplicity and high level of standardization. They usually consist of reservoirs for previous accumulation and storage of manure, bioreactors with management, mixing and heating systems, reservoirs for storage and further processing of the dumped biomass, pumps for loading and unloading, the equipment for keeping and transportation of biogas, and also the heat power module for heating and electricity generation.

To the second category refers: powerful installations on the manure processing, which designed as for using in large-scale livestock enterprises, and for the satisfaction of general requirements for several farms. Usually such gas installations are used mixing mass: dung and other types of organic waste, which has some blocks. The block of previous storage contains separate reservoirs for both manure and other organic substances, and the reservoirs for biomass homogenization. Bioreactor is the steel container, equipped by the systems of automatic management. The dumped mass of household used as an organic fertilizer, received biogas is turned into thermal and electric energy using the universal heat power module. Heat Exchangers are applied in these biogas installations, its use heat of had already processed weight, for a warming up raw material at an entrance. The anaerobic fermentation occurs usually in a thermophilic mode (which conforms to the requirements more). The efficiency of installations depends on its sizes directly; the powerful enterprises have the smaller processing cost per one cubic meter of biomass.

The third category of biogas installations consists of it's the most powerful units which are used for processing of organics with various origin. They allow receiving biogas both as from firm, and liquid organic substances. Great attention is paid to preparation raw materials for a digestion. In certain cases, the additional operation of hydrolysis of biomasses is 
imposed for increasing the efficiency of an anaerobic fermentation. Fermented waste with the big content of solid can be exposed to further processing for improvement it's quality as an organic fertilizer by an aerobic composting, and liquid can be utilized after additional cleaning (Klimenko, 2006; Matveev, 2004).

Outputs of products of animal husbandry in Ukraine have been decreasing over the last 10 years but the volume of an exit of manure is still considerable.

For the evaluation of volumes of manure in Ukraine we will try to compare it with the volume of EU countries and the whole world.

The term manure includes both urine and dung (i.e., both liquid and solid material) produced by livestock. More specifically, $\mathrm{CH}_{4}$ gas is produced by anaerobic decomposition of manure stored or treated, while $\mathrm{N}_{2} \mathrm{O}$ is produced directly by nitrification and de-nitrification processes in the manure, and indirectly by nitrogen $(\mathrm{N})$ volatilization and re-deposition processes, as well as from leaching of manure $\mathrm{N}$.

Data for buffalo, sheep, goats, camels, llamas, horses, mules, asses, pigs, ducks, turkeys, chickens and dairy cattle are taken directly from FAOSTAT (domain: Production), non-dairy cattle is derived from FAOSTAT categories, specifically as cattle minus dairy cattle.

Figure 2. The EU share in manure management in the world

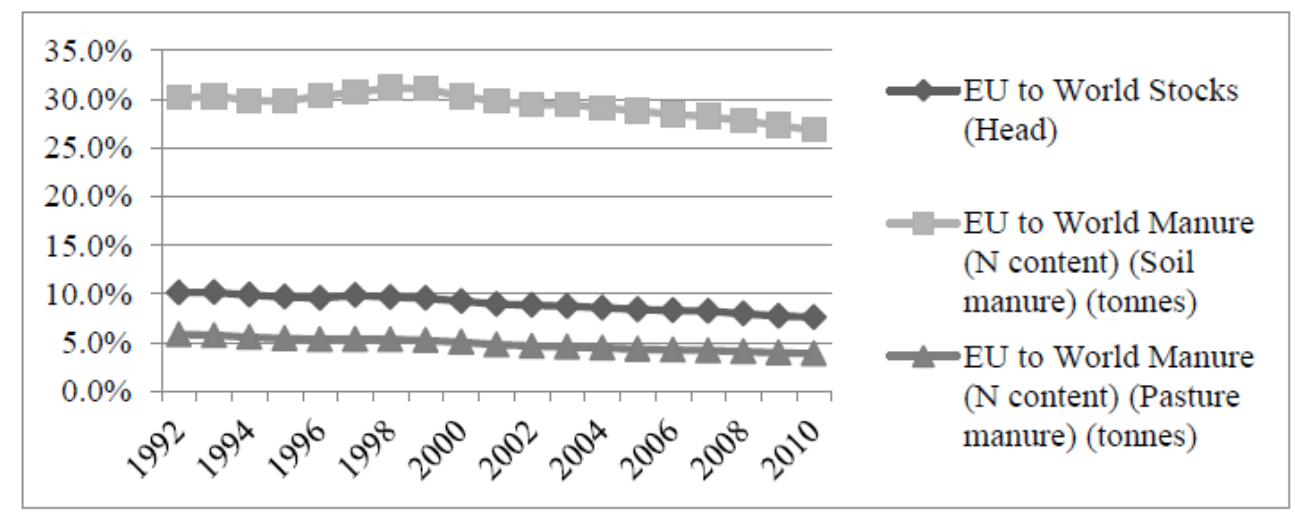

Source: FAOSTAT

Environmental pollution isn't limited by the state border that is why it is necessary to estimate volumes of harmful emissions in comparison with other states and together to carry out measures for their minimization. That is why, universal and European (EU) indicators were chosen for comparison with manure volumes in Ukraine. Estimating the amount of manure produced by animal husbandry in the EU, we can note that a share of the EU in universal stockbreeding decrease within the last two decades (1992-2010). It testifies that in the other countries of the world the livestock of animals increasing more rapidly than in EU countries (Figure 2).

The contribution of Ukraine in universal producing manure is much more modest than in the EU (Figure 3). 
Figure 3. The Ukrainian share in producing manure in the world

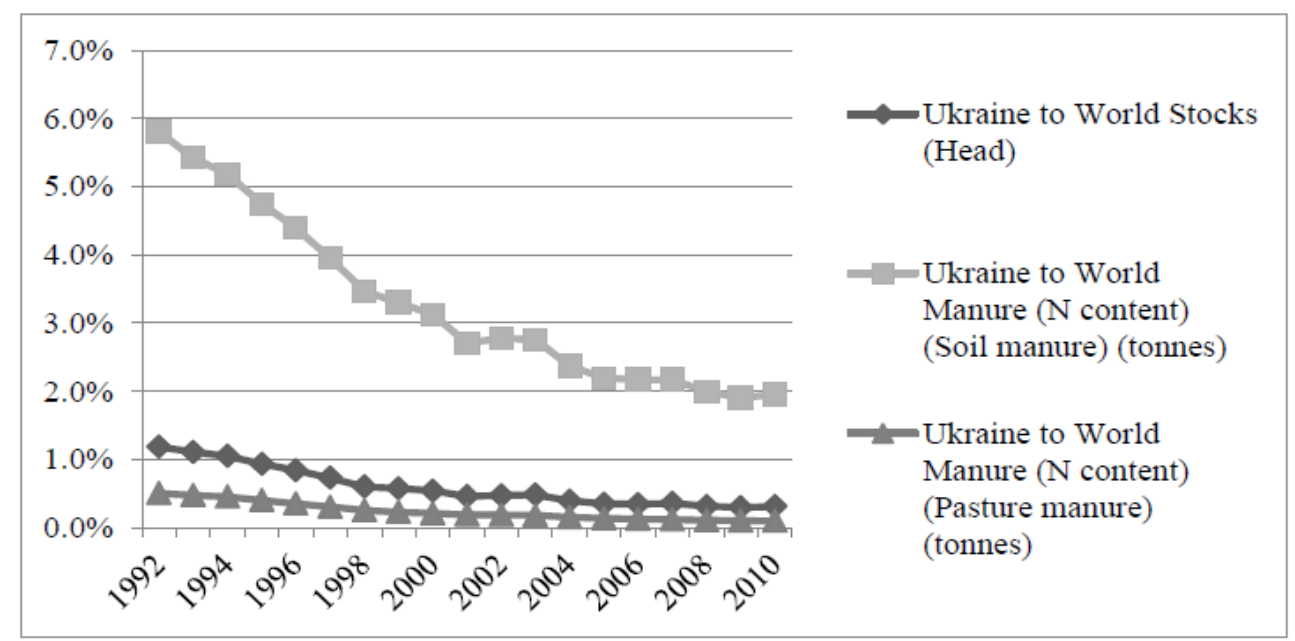

Source: FAOSTAT

Share of a universal producing of dung in Ukraine is decreased for the last two decades. So, if in 1992 the share of a fertilizing the soil in Ukraine made about 6\%, in 2010 this index was $2 \%$. It testifies for the considerable recession of a livestock of animals in Ukraine.

The Ukrainian share of producing the dung in EU is slight, in 2010 the share of dung brought in the soil made about 7\%. Thus mentioned share in 1992 was about 20\% (Figure 4).

Figure 4. The Ukrainian share in producing manure in the EU

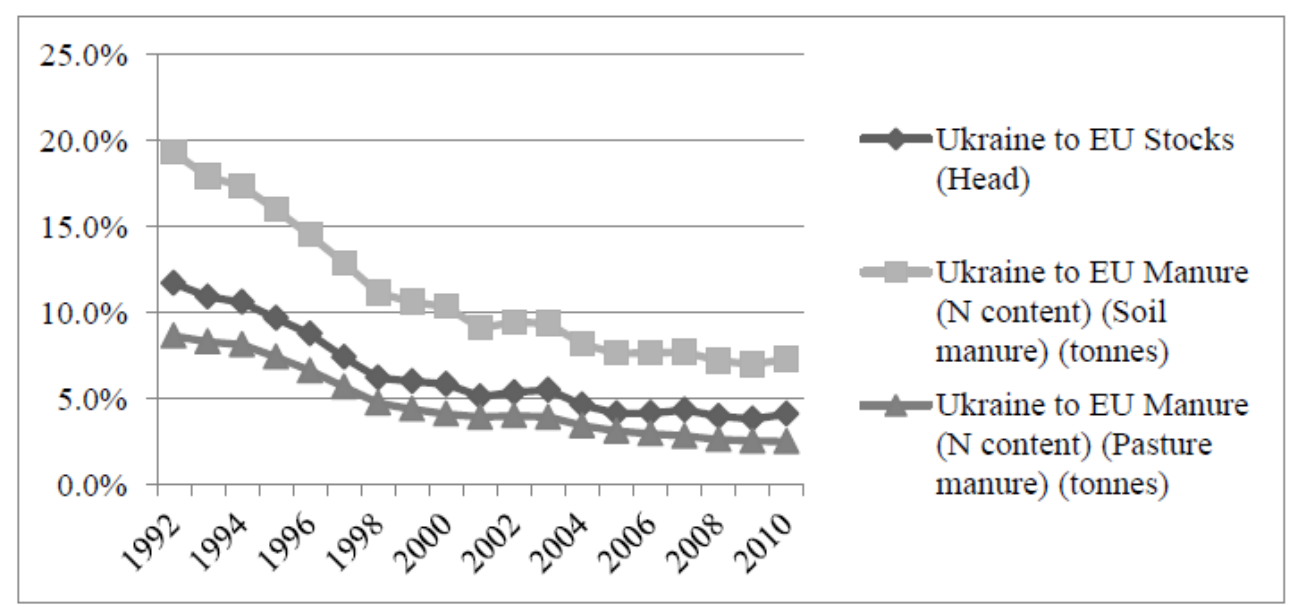

Source: FAOSTAT 
Figure 5. Manure ( $\mathrm{N}$ content), (Manure Management) tonnes, Ukraine

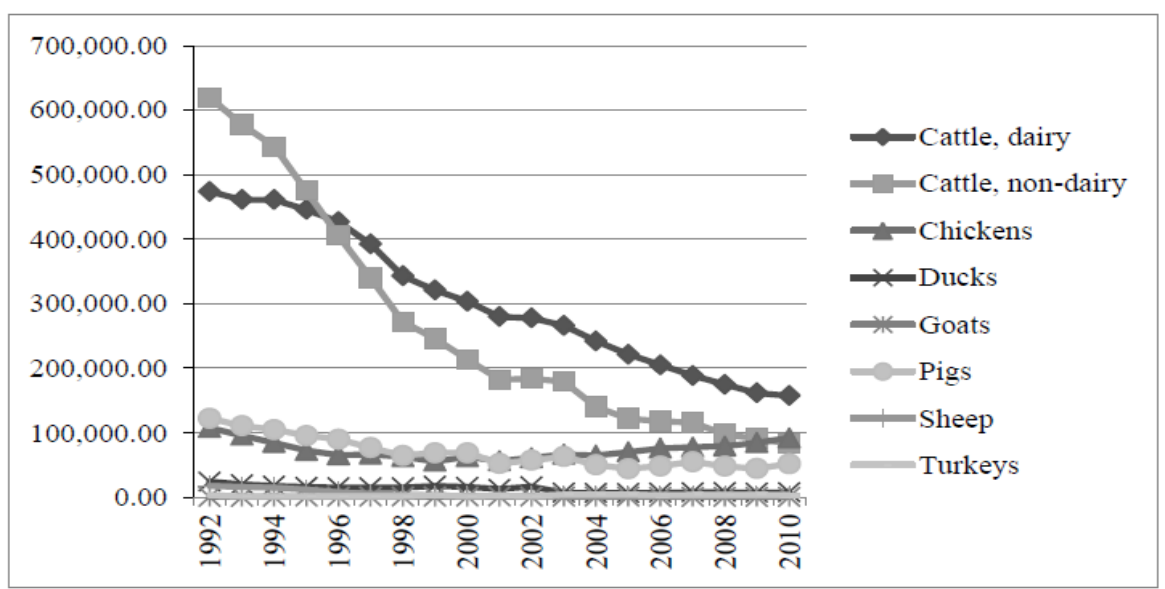

\section{Source: FAOSTAT}

The volumes of substrate greatly decreased in 2010 to the indicator in 1992, it was about $29 \%$, during the analysed period. The recession was occurred on all species of animal. But the volumes of substrate remain is still considerable, so in 2010 the volume was - 400 thousands of tons.

During the analysed period 1992-2010 Ukraine has reduced the volumes of manure due to decreasing a livestock of animals. The only positive side that can be considered is decreasing the falling rates of a productive share of manure in Ukraine.

In 2012 in Ukraine the physical volumes of manure were about 5062 thousand tons that make up about $1 \%$ of all formed wastage in Ukraine (Table 1). Besides, volumes of wastage have been increasing from year to year. So, the need of processing the wastage becomes more and more necessary for the purpose of decreasing a harmful effect on an environment.

Table 1.Generation of waste in Ukraine by categories of materials

\begin{tabular}{|l|c|c|c|c|}
\hline \multicolumn{1}{|c|}{ Indicators } & Units of measure & $\mathbf{2 0 1 0}$ & $\mathbf{2 0 1 1}$ & $\mathbf{2 0 1 2}$ \\
\hline \multirow{2}{*}{ Total } & thousand tons & 419191,8 & 447641,2 & 450726,8 \\
\cline { 2 - 5 } & $\%$ & 100 & 100 & 100 \\
\hline \multirow{2}{*}{ Animal and vegetable waste } & thousand tons & 15424,2 & 12820,6 & 12850 \\
\cline { 2 - 5 } & $\%$ & 3,7 & 2,9 & 2,85 \\
\hline $\begin{array}{l}\text { Animal waste received from } \\
\text { the manufacture of food } \\
\text { products and preparations }\end{array}$ & thousand tons & - & 360,9 & 267,5 \\
\cline { 2 - 5 } & $\%$ & - & 0,1 & 0,1 \\
\hline \multirow{2}{*}{$\begin{array}{l}\text { Animal excrements, urine and } \\
\text { manure }\end{array}$} & thousand tons & 3796,9 & 7754,6 & 5062 \\
\cline { 2 - 5 } & $\%$ & 0,9 & 1,7 & 1,1 \\
\hline
\end{tabular}

Source: www.ukrstat.gov.ua 
Generally, the activity of waste recycling can be profitable. You can receive a lot of secondary raw materials because of the results of processing.

Policies based on extension and financial and regulatory incentives will also play an important role in stimulating the adoption of grazing management practices. Again, the economic attractiveness of the various practices for enhancing soil carbon stocks will help to inform which combination of these policies is better placed to support these practices (Gerber et al., 2013).

Further, while research and development initiatives are essential for the provision of new and improved mitigation options for the sector, financial regulatory incentives can also drive mitigation technology development by the private sector. By making emissions costly or mitigation profitable, these policies will motivate the livestock industry to search for and develop less emission-intensive practices and technologies (Gerber et al., 2013).

As I have mentioned above, manure processing has three useful factors. Taking into account that the cost of energy resources grows constantly, implementation of biogas installations on the enterprises with animal husbandry will allow making the costs of energy resources lower and fertilize annually.

Let's try to determine the volume of biogas which is possible to produce from all quantity of a substratum made in Ukraine. In 2010 volumes of substrata was 400 thousand tons of all animal species. According to the source (ATSL) it is possible to determine the volumes of biogas which can be allocated from different types of substrata. As it is impossible to find the data of substrata types, we assume that the minimum quantity of biogas can be made from a substratum - the fluid manure of cattle, which is no less than $25 \mathrm{~m}^{3}$ per a substratum ton. Based on these data, we can affirm, that in Ukraine the potential volume of biogas can be 1 million $\mathrm{m}^{3}$. Thus, 54 million $\mathrm{m}^{3}$ of natural gas was used in Ukraine in 2012 (UGM, 2012).

One of a factor of decreasing of greenhouse gases emission from a livestock is its government support by compensation of share of an interest rate of the credits for new technologies which will reduce the greenhouse gases emissions.

Agriculture in global economics is one of the most protected and "closed" branches. The main method of protection is to give a huge volume of subsidies to the agricultural producers. Annual expenses of WTO member countries for agriculture reach dozens of millions US dollars (Erohin, Ivolga, 2012). Considering the fact that Ukraine is a member of WTO, but by this organization support of agriculture is restricted and unlimited in the different directions, in particular, support of biogas production may be unlimited by compensation of an interest rate. So, implementation the programs of a state support of biogas production by agricultural enterprises can promote their higher development and profitability.

As in Ukraine there is no similar program, it is necessary to enter such program in our motherland, considering a wide experience of it implementation in other countries in the world. In recent years is observed chronic insufficient financing of all state support programs 
connected with agricultural production (Zhyk, 2011). Although, you should not hope for the fast implementation of the program, mentioned above. But the source of financial resources still exists, for introduction the state support program for agricultural producers who reduces emissions be a greenhouse gases.

One more factor causing the need of introduction of biogas installations is the Kyoto Protocol, according to which Ukraine has undertook to reduce emissions of greenhouse gases.

Carbon markets, in which carbon emission permits and reductions can be traded, have been put in place by a number of countries and jurisdictions to curb GHG emissions. Putting aside the lack of concerted political commitment to reduce emissions, which affects the penetration of all mitigation policies alike, carbon markets have, in general, functioned reasonably well, and are slowly growing rather than shrinking (Gerber et al., 2013).

Despite this progress, carbon markets currently provide very limited mitigation incentives for the sector. They either do not include livestock sector emissions or provide only a limited coverage. This is partly due to difficulties in accurately and cost-effectively measuring emission reductions. However, with continued research and development to improve measurement methodologies and the ongoing evolution of market-based instruments, the role of carbon markets should increase over the long term (Gerber et al., 2013).

The volume and value of emissions traded on the Kyoto-compliant markets as a whole grew by 114 percent and 31 percent, respectively, between 2008 and 2011. The volume and value of emission allowances traded in the EU Emission Trading Scheme, the world's largest and most liquid carbon market, grew by 153 percent and 47 percent, respectively, over the same period. However, the combined effects of the current global recession and lower than projected emissions have caused an oversupply in EU emission allowances, and prices have been falling since 2008 .

Furthermore, these market-based mechanisms have not played a role in the mitigation of livestock emissions because none of them includes agriculture, except for the Carbon Pricing Mechanism in Australia which is linked to a carbon EU Emission Trading Scheme caused a large fall offset scheme known as the Carbon Farming Initiative (Gerber et al., 2013).

In addition to carbon markets, there is a range of complementary sources of mitigation finance. These include multilateral funding sources such as the Green Climate Fund, the World Bank, and the Global Environment Facility, as well as domestic funding sources such as national development banks and nationally sponsored climate funds (e.g. the Spanish Carbon Fund), which are making increasing contributions to mitigation finance. There may also be good opportunities for the public sector to design financial instruments to attract private sector coinvestment into mitigation projects, perhaps by managing risks that the private sector is not willing to take on (Gerber et al., 2013). 


\section{Conclusion}

Taking part in the trade system of greenhouse gases emission there is a possibility of mobilization of financial resources for financing the program of biogas production. So, introduction of a state support program of biogas production from animal substrata has a potential source of financial resources - trade in limits on harmful emissions. The potential minimum volume of biogas is 1 million $\mathrm{m}^{3}$ in Ukraine. While reduction of harmful emissions from animal husbandry will be reached and received an organic fertilizer ready to entering into the soil.

\section{References}

1. United Nations Population Division, DESA, available at: www.un.org/en/development/ desa/population/events/pdf/expert/6/worldpoptotals.pdf

2. Gerber, P. J., Steinfeld, H., Henderson, B., Mottet, A., Opio, C., Dijkman, J., Falcucci, A., Tempio, G. (2013): Tackling climate change through livestock - A global assessment of emissions and mitigation opportunities, FAO, Rome, available at: www.fao.org/docrep/018/i3437e/i3437e.pdf

3. IPCC (2006): 2006 IPCC Guidelines for National Greenhouse Gas Inventories, Prepared by the National Greenhouse Gas Inventories Programme, Eggleston, H. S., Buendia, L., Miwa, K., Ngara, T., Tanabe, K. (Eds), IGES, Hayama, Japan.

4. The Association for Technology and Structures in Agriculture, available at: www. ktbl.de

5. Erokhin, V., Ivolga, A. (2012): How to Ensure Sustainable Development of Agribusiness in the Conditions of Trade Integration: Russian Approach, International Journal of Sustainable Economies Management, vol. 1(2), pp. 12-23.

6. Ринокгазутанафтиукраїниза 2012 piк, available at: http://www.credit-rating.ua/ img/st img/AS/2013/15.04.2013/gas_neft 2012.pdf

7. The World Bank, available at: www.worldbank.org

8. Food and Agriculture Organization of the United Nations (FAO), Rome, available at: www.fao.org

9. Klimenko, V. (2006): Сільськогосподарськібіогазові установки: зарубіжнийдосвід, Техніка АПК, № 10, pp. 22-26.

10. Matveyev, Y. (2004): Біогазовастанція. Українськийдосвід, Зелена енергетика, № 1, pp. 4-6.

11. Matveyev, Y. (2004): Біогаз на полігонах ТПВ, Зеленаенергетика, № 4, pp. 17-19.

12.Zhuk, V. M. (2001): Стан та розвиток спеціальних режимів оподаткування аграрногобізнесу, Фінанси України, № 7, pp. 33-42.

13.Ukraine committee of statistics, available at: www.ukrstat.gov.ua 